\title{
ENGINEERING GEOLOGICAL MAPPING ON SLOPE DESIGN IN THE MOUNTAINOUS AREA OF SABAH WESTERN, MALAYSIA
}

\author{
Rodeano Roslee ${ }^{1,2^{*}}$, Felix Tongkul ${ }^{1,2}$ \\ ${ }^{1}$ Natural Disaster Research Centre (NDRC), Universiti Malaysia Sabah. \\ ${ }^{2}$ Faculty of Science and Natural Resources (FSSA), Universiti Malaysia Sabah. \\ *Corresponding Author Email: rodeano@ums.edu.my
}

This is an open access article distributed under the Creative Commons Attribution License, which permits unrestricted use, distribution, and reproduction in any medium, provided the original work is properly cited.

\section{ARTICLE DETAILS}

\section{Article History:}

Received 26 June 2018 Accepted 2 July 2018

Available online 1 August 2018

\section{ABSTRACT}

The geology in the mountainous area of Sabah western provides a favourable setting for engineering geological instability. The area is underlain by the Trusmadi Formation (Palaeocene to Eocene age), the Crocker Formation (Late Eocene to Early Miocene age) and vary recent Quaternary alluvial materials which are still being deposited. The argillaceous nature and intense deformation suffered by the Trusmadi Formation and the highly jointed sandstone and mudstone beds of the arenaceous Crocker Formation makes them highly susceptible to weathering and instability. The weathered materials are unstable and may experience sliding due to by high pore pressure and intensively of geomorphological processes. In this study, a total of 20 selected critical slope failures were studied and classified into two main groups; rock slope (ten) and soil slope (ten). Soil slope failures normally involved large volumes of failed material as compared much rock slopes, where the failures are mostly small to medium. Kinematics rock slope analyses indicates that the variable potential of circular, planar, wedges, and toppling failures modes as well as the combination of more than one mode of aforementioned failure. Rock and soil slopes stability analysis indicates that the factor of safety value as unsafe ( 0.56 to 0.95$)$. The geological influence had transformed the slopes in the Sabah mountainous area to be highly unstable and susceptible to landslide occurrences. Six (6) related main parameters to the landslide occurrence in the study area were attributed; 1) local and regional geology, 2) hydrological and geohydrological, 3) mineralogical and micro structures, 4) local discontinuities structures, 5) physical and engineering properties of soil and rock, and 6) geomorphological processes which can help in evaluating landslide problems. Therefore, development planning has to consider the slope hazard and risk management. This engineering geological mapping may play a vital role in disaster risk reduction programme in Sabah to ensure the public safety and to be extend with different environment.

\section{KEYWORDS}

Engineering Geology, Mountainous Area, Slope Design and Sabah Western.

\section{INTRODUCTION}

The rapid development since the early nineties (90's) had a spill over effect in the mountainous area of Sabah western where lands was cleared for the construction of highways, tourism activities, agricultural activities and several other heavy infrastructures. These activities had, besides spurring economic growth, also caused landslide hazard and risk problems. Slope failure occurrences have presently impact the community and its socio-economic development, in addition to adding a strain to the government in the heightened costs of repair and maintenance especially along the road connecting from Ranau to Tambunan, Penampang to Tambunan and Kimanis to Keningau areas. Slope failure is a form of passive geological processes and meteorology where rate and size were upgraded by human being activities.

There was some research conducted and published in documented research reports, international proceeding or manuscript close to the study area such as Mineral and Geosciences Department of Malaysia (MGDM) and others with their documented research report projects have mapped some potential or active landslide areas in the consideration and evaluation of geological contributions factors [1-12]. There are more discussing of physical characterization with their engineering materials, slope stability analysis and design or repairing the slopes [1,3,4, 6-8]. While some researchers have conducted detail study on eight (8) systems landslide hazard complex in Kundasang's town area, Ranau, Malaysia
$[2,13]$.

This paper deals with the engineering geological mapping on 20 selected critical slopes with the aims of analysis the physical and mechanical properties of soil and rock, calculate the factor of safety for slopes and to evaluate the main factors contributing to slope failures. The study area lies centrally on the western coast of Sabah pass through the Crocker Range roughly about longitude line E $116^{\circ} 00^{\prime}$ to $\mathrm{E} 116^{\circ} 45^{\prime}$ and latitude line $\mathrm{N}$ $05^{\circ} 15^{\prime}$ to $\mathrm{N} 05^{\circ} 50^{\prime}$ (Figure 1). The mainland part of the study area is the most accessible. Good networks of sealed and unsealed roads connecting most of the prime villages around it. Part of the roads is constructed across the steep, hummocky and rugged slopes, creating problems of slope and road stability especially during periods of intense rainfall. Since it's developed, the problem of slope stability has adversely affected the use of the road. 


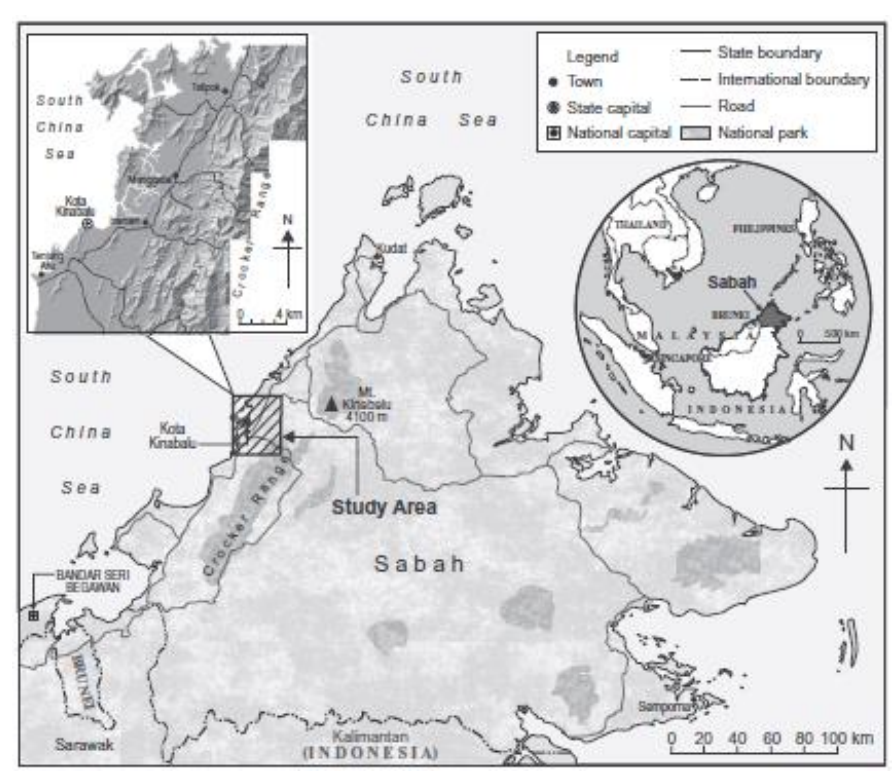

Figure 1: Location of the study area

\section{METHODOLOGY}

Several classifications can be used to describe slope failures. For this study in the topics, the types of slope failures were classified according to the proposals of a researcher [14]. In this study, only failures with volume exceeding $10 \mathrm{~m}^{3}$ were considered, since failures involving smaller volume did not generally affect the road users. On the basis, the slope failure was divided into three groups: small $\left(10-50 \mathrm{~m}^{3}\right)$, Medium $\left(50-500 \mathrm{~m}^{3}\right)$ and Large ( $>500 \mathrm{~m}^{3}$ ). For each slope failures that were studied (Figure 2), type of failures, the geometry of the slope, geological background characteristics, weathering characteristics, ground water condition, discontinuity characteristics, physical and mechanical of the sliding materials and an interpretation of the factors causing the failure based on field observations were recorded. Soil and rock samples from the study area were collected during field mapping for detailed laboratory analysis.

The laboratory works such as classification tests (grain size, atterberg limit, shrinkage limit, specific gravity and water content), permeability test, consolidated isotropically undrained (CIU) test, rock uniaxial compressive strength and point load test were carried out in compliance and accordance to British Standard Code of Practice BS 5930-1981 (Site Investigation), British Standard Code of Practice BS 1377-1990 (Method of Test for Soils for Civil Engineering Purposes) and ISRM [15-19].

For the soil slopes stability analysis, using the "SLOPE/W" software was done successfully to determine susceptibility of the slopes to shallow noncircular slides based on the determination of factor of safety values, which are common in the study area [20]. The advantage of these methods is that in its limit equilibrium calculations, forces and moments on each slice is considered.

Discontinuity orientation data has been collected from ten (10) selected of rock slope failure by random method. For each rock slope failures that were studied, the geometry of the slope, dip direction and dip value, persistence, roughness, unevenness, aperture, infilling material, water condition, weathering, geological background characteristics, engineering properties of the sliding materials and an interpretation of the factors causing the failure critical discontinuities plane, potential mode and rock slope stability analysis has been performed by RockPack III program [21].

\section{LOCAL GEOLOGY AND ENGINEERING GEOLOGY CHARACTERISTICS}

The geology of the study area is made up of sedimentary rock of the argillaceous Trusmadi Formation (Palaeocene to Eocene age), the arenaceous Crocker Formation (Late Eocene age) and Quaternary Alluvium Deposits (Table $1 \&$ Figure 2). The Trusmadi Formation consists mostly of dark grey shale with thin bedded sandstones, typical of a turbidite deposit. In certain areas, this unit has been subjected to low metamorphism, producing slates, phyllites and meta-sediments and intense tectonic deformation producing disrupted or brecciated beds. Quartz and calcite veins are quite widespread within the crack deformed on sandstone beds. The shale is dark grey when fresh but changes light grey to brownish when weathered.

The Trusmadi formation generally shows two major structural orientations NW-SE and NE-SW [10]. The layered nature of the sandstone and shale of the Crocker Formation are generally oriented between N325E to N010E and show steep dips (50-85 degrees) eastward. Large scale folds (> 100 meter wavelength), faults (several meters wide) and more than four (4) set joints orientation are common in the study area.

The sandstone-shale contact is easily accessible by water and such contact seepage may weaken the shale surface and cause slides and falls within the formation. Interbedded sandstone and shale may also present problems of settlement and rebound. The magnitude, however, depends on the character and extent of shearing in the shale. The strength of the sandstone will also depend on the amount and type of cement-matrix material occupying the voids. The sandstones are compacted and in grain to grain contact with each other. Instead of chemical cement (vein) or matrix, the pores are filled by finer-grained sands to silt-sized materials or squeezed rock fragments. The absence of chemical cement reduces the strength of the sandstone especially when it is weathered or structurally disturbed.

The shale units have an adequate strength under dry conditions but lose this strength when wet [6]. During the rainy season, the shale becomes highly saturated with water which increases the water pressure and reduces resistances to sliding and falling especially within the sandstonesshale contact. This condition, in addition to varying amounts of bitumen and levels of degradation, makes shale unpredictable and unsuitable for road construction sites. Its unstable nature can be remedied by proper management of soaking and draining of water from the rock or along the sandstone-shale contact.

The alluvium is mainly represent unconsolidated alluvial sediment on river terraces and weathered product materials composed of unsorted to well-sorted, sand, silt and clay of varying proportions which were derived from the bed rocks. They occur in irregular lenses varying in the form and thickness. The alluvium may also consist of very thin layer of organic matter and characterized as soft, compressible and may be prone to settlement. 
Table 1: Lithologic characteristics

\begin{tabular}{|c|c|c|c|c|c|c|c|}
\hline $\begin{array}{l}\text { Rock } \\
\text { Formation }\end{array}$ & Litholigic Units & $\begin{array}{l}\text { Average } \\
\text { Thickness } \\
\text { (cm) }\end{array}$ & & Sedimentary Structures & Fossil & $\begin{array}{l}\text { Depositional } \\
\text { Mechanism }\end{array}$ & $\begin{array}{l}\text { Depositional } \\
\text { Environment }\end{array}$ \\
\hline $\begin{array}{l}\text { Alluvium } \\
\text { and } \\
\text { Colluvium }\end{array}$ & $\begin{array}{l}\text { Alluvial terraces } \\
\text { and flood plains }\end{array}$ & - & $\begin{array}{l}\text { Angular to sub } \\
\text { rounded } \\
\text { sandstone } \\
\text { blocks in a } \\
\text { silty matrix }\end{array}$ & - & - & $\begin{array}{l}\text { Alluvial terraces and } \\
\text { flood plains }\end{array}$ & - \\
\hline \multirow{5}{*}{$\begin{array}{l}\text { Crocker } \\
\text { Formation }\end{array}$} & $\begin{array}{l}\text { Massive Sandstone } \\
\text { (Facies B) }\end{array}$ & $100-1,000$ & $\begin{array}{l}\text { Quarzarenite } \\
\text { and } \\
\text { Sublitharenite } \\
\text { (Immature) }\end{array}$ & \multirow{5}{*}{$\begin{array}{l}\text { Inorganic Structures } \\
\qquad \text { Pre-depositional } \\
\text { 1. Climbing Ripple } \\
\text { 2. Ripple Marks } \\
\text { 3. Tool Marks } \\
\text { 4. Scour Marks } \\
\quad \text { Syn - depositional } \\
\text { 1. Bedding } \\
\text { 2. Lamination } \\
\text { 3. Graded bedding } \\
\text { 4. Cross bedding } \\
\text { 5. Convolute lamination } \\
\quad \text { Post-depositional } \\
\text { 1. Slump structures } \\
\text { 2. Soft sediment fault } \\
\text { 3. Lutite clasts } \\
\text { 4. Load structures } \\
\text { 5. Ball and pillow } \\
\text { structures } \\
\text { 6. Water escapes }\end{array}$} & \multirow{5}{*}{$\begin{array}{ll}\text { 1. } & \text { Bathysip } \\
\text { hon spp } \\
\text { 2. } \\
\text { Glomosp } \\
\text { ira sp } \\
\text { 3. Cyclam } \\
\text { mina } \\
\text { cancellat } \\
\text { a } \\
\text { (Brady) } \\
\text { 4. Haploph } \\
\text { ragmoid } \\
\text { eswalter } \\
\text { i } \\
\text { (Grzybo } \\
\text { wski) } \\
\text { 5. Trocha } \\
\text { mminoi } \\
\text { des sp. }\end{array}$} & Grain flow deposits & $\begin{array}{l}\text { Upper fan to } \\
\text { Middle fan }\end{array}$ \\
\hline & $\begin{array}{l}\text { Thick bedded } \\
\text { Sandstone } \\
\text { (Facies C) }\end{array}$ & $\begin{array}{l}10 \quad-\quad 50 \\
\text { (Sandstone) } \\
1-15 \text { (Shale) }\end{array}$ & $\begin{array}{l}\text { Moderately } \\
\text { well sorted to } \\
\text { moderately } \\
\text { sorted }\end{array}$ & & & $\begin{array}{l}\text { High density, high } \\
\text { velocity turbidity } \\
\text { currents } \\
\text { (Proximal turbidites) }\end{array}$ & $\begin{array}{l}\text { Outer fan } \\
\text { localized in } \\
\text { channels and in } \\
\text { the prograding } \\
\text { depositional } \\
\text { lobes. }\end{array}$ \\
\hline & $\begin{array}{l}\text { Thin bedded } \\
\text { Sandstone } \\
\text { (Facies D/E) }\end{array}$ & $\begin{array}{l}3 \quad-\quad 5 \\
\text { (Sandstone) } \\
5-10 \text { (Shale) }\end{array}$ & $\begin{array}{l}\text { (Mature and } \\
\text { Immature) }\end{array}$ & & & $\begin{array}{l}\text { Waning or low } \\
\text { velocity turbidity } \\
\text { currents } \\
\text { (Distal turbidites) }\end{array}$ & $\begin{array}{l}\text { Middle to outer } \\
\text { fan and } \\
\text { particularly } \\
\text { basin plain }\end{array}$ \\
\hline & $\begin{array}{l}\text { Slumped } \\
\text { (Facies F) }\end{array}$ & - & - & & & $\begin{array}{l}\text { Turbidite and debris } \\
\text { flow sedimentation }\end{array}$ & $\begin{array}{l}\text { Shelf to lower } \\
\text { slope and partly } \\
\text { in the channels } \\
\text { of inner fan, } \\
\text { middle fan and } \\
\text { basin plain }\end{array}$ \\
\hline & $\begin{array}{l}\text { Red / Grey Shale } \\
\text { (Facies G) }\end{array}$ & $\begin{array}{l}1-2 \text { (Siltstone) } \\
10 \quad-\quad 50 \\
\text { (Mudstone) }\end{array}$ & - & & & Debris flow & $\begin{array}{l}\text { Plain basin, } \\
\text { middle fan and } \\
\text { slope region }\end{array}$ \\
\hline \multirow{6}{*}{$\begin{array}{l}\text { Trusmadi } \\
\text { Formation }\end{array}$} & $\begin{array}{l}\text { Massive Sandstone } \\
\text { (Facies B) }\end{array}$ & $100-1,000$ & $\begin{array}{l}\text { Quarzarenite } \\
\text { (Immature) }\end{array}$ & \multirow{6}{*}{$\begin{array}{l}\text { structures } \\
\text { Organic Structures } \\
\text { Plant remains } \\
\text { Trace fossil } \\
\text { Pre - depositional } \\
\text { traces } \\
\text { 1. Paleodictyon } \\
\text { minimum } \\
\text { Cosmorhaphe sinuosa } \\
\text { Post - depositional traces } \\
\text { 1. Post - depositional } \\
\text { burrow type } 1 \\
\text { 2. Post - depositional } \\
\text { burrow type } 2 \\
\text { 3. Post - depositional } \\
\text { burrow type } 3 \\
\text { 4. Post - depositional } \\
\text { burrow type } 4 \\
\text { 5. Post - depositional } \\
\text { burrow type } 5\end{array}$} & \multirow{6}{*}{ 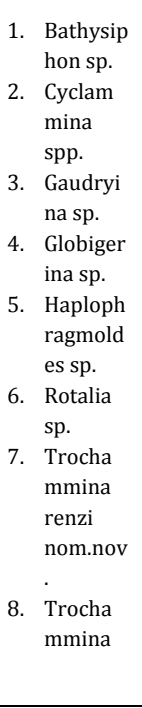 } & Grain flow deposits & $\begin{array}{l}\text { Upper fan to } \\
\text { Middle fan }\end{array}$ \\
\hline & $\begin{array}{l}\text { Thick bedded } \\
\text { Sandstone } \\
\text { (Facies C) }\end{array}$ & $\begin{array}{l}10 \quad-\quad 50 \\
\text { (Sandstone) } \\
1-15 \text { (Shale) }\end{array}$ & $\begin{array}{l}\text { Moderately } \\
\text { well sorted } \\
\text { to } \\
\text { moderately } \\
\text { sorted }\end{array}$ & & & $\begin{array}{l}\text { High density, high } \\
\text { velocity turbidity } \\
\text { currents } \\
\text { (Proximal turbidites) }\end{array}$ & $\begin{array}{l}\text { Outer fan } \\
\text { localized in } \\
\text { channels and in } \\
\text { the prograding } \\
\text { depositional } \\
\text { lobes. }\end{array}$ \\
\hline & $\begin{array}{l}\text { Thin bedded } \\
\text { Sandstone } \\
\text { (Facies D/E) }\end{array}$ & $\begin{array}{l}3 \quad-\quad 5 \\
\text { (Sandstone) } \\
5-10 \text { (Shale) } \\
\end{array}$ & $\begin{array}{l}\text { (Mature and } \\
\text { Immature) }\end{array}$ & & & $\begin{array}{l}\text { Waning or low } \\
\text { velocity turbidity } \\
\text { currents } \\
\text { (Distal turbidites) }\end{array}$ & $\begin{array}{l}\text { Middle to outer } \\
\text { fan }\end{array}$ \\
\hline & $\begin{array}{l}\text { Chaotic } \\
\text { (Facies F) }\end{array}$ & - & - & & & $\begin{array}{l}\text { Turbidite and debris } \\
\text { flow sedimentation }\end{array}$ & $\begin{array}{l}\text { Shelf to lower } \\
\text { slope and partly } \\
\text { in the channels } \\
\text { of inner fan }\end{array}$ \\
\hline & $\begin{array}{l}\text { Red / Grey Shale } \\
\text { (Facies G) }\end{array}$ & $\begin{array}{l}1-2 \text { (Siltstone) } \\
10 \quad-\quad 50 \\
\text { (Mudstone) }\end{array}$ & - & & & Debris flow & $\begin{array}{l}\text { Plain basin, } \\
\text { middle fan and } \\
\text { slope region }\end{array}$ \\
\hline & $\begin{array}{l}\text { Pebbly Mudstone } \\
\text { (Facies H) }\end{array}$ & - & - & & & Debris flow & $\begin{array}{l}\text { Slope region } \\
\text { especially in the } \\
\text { feeder channel } \\
\text { zone }\end{array}$ \\
\hline
\end{tabular}

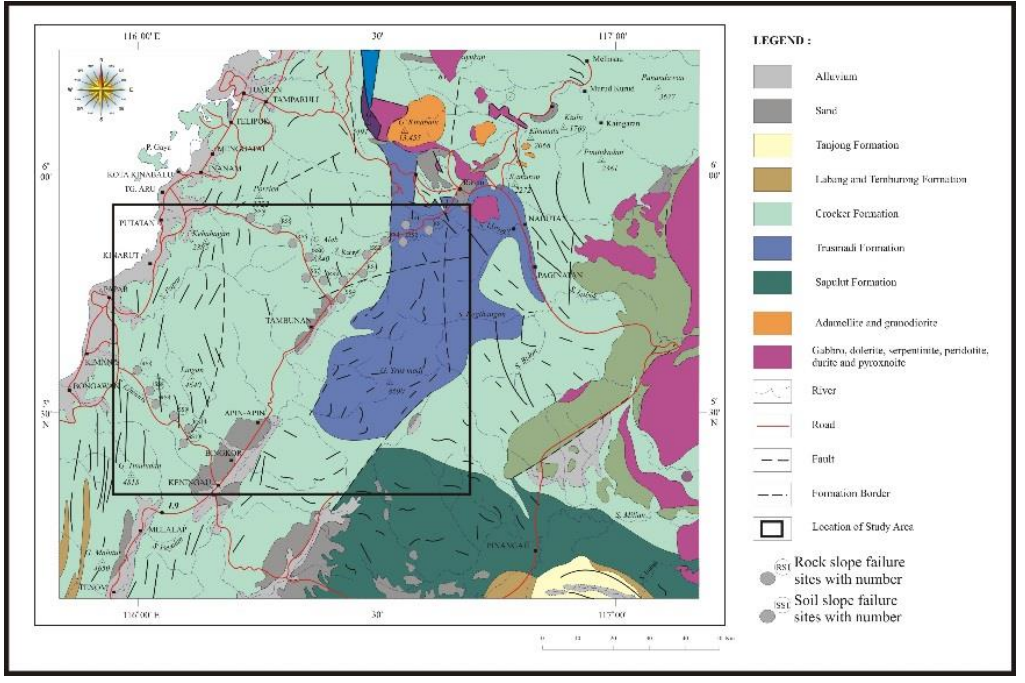

Figure 2: Geological map with their slope failure locations 


\section{SLOPE STABILITY ANALYSIS}

In this study, a total of 20 selected critical slope failures were studied and classified into two main groups: rock slope and soil slope. Failures in soil slopes (including embankments) are $10(50 \%)$ whereas 10 of all failures ( $50 \%$ ) of rock slope (Figures 3 to 5). Results of a detailed analysis of soil slope stability are presented in Table 2 . Considering cut slopes, all the major lithologies are involved showing that this type of failure is mostly controlled by lithology. The failure volume scale involved generally small to large in size possibly endangering road users. In term of weathering grades, the materials that underwent failure were in the ranges from grade IV to VI (Figures 6 to 9). Intense water runoff and emitted water seepage is the main factor causing failure with the depth of weathering influencing the volume of material that fails. It appears that grade IV to grade $\mathrm{V}$ materials actually failed with the overlying grade VI material sliding or slumping down together with this material during failure.

Physical and mechanical properties of 80 soil samples indicated that the failure materials mainly consist of poorly graded to well graded materials of sandy clay and clayey silt soils, which characterized by low to intermediate plasticity content $(12 \%$ to $21 \%)$, containing of inactive to normal clay ( 0.34 to 1.47$)$, very high to medium degree of swelling (6.10 to 10.54 ), variable low to high water content ( $5 \%$ to $35 \%$ ), specific gravity ranges from 2.51 to 2.77 , low permeability $\left(9.15 \times 10^{-3}\right.$ to $3.28 \times 10^{-3}$ $\mathrm{cm} / \mathrm{s}$ ), friction angle $(\phi)$ ranges from $7.72^{\circ}$ to $28.90^{\circ}$ and cohesion (C) ranges from $5.11 \mathrm{KPa}$ to $24.44 \mathrm{KPa}$. Soil slopes stability analysis indicates that the factor of safety value as unsafe (0.68 to 0.95). The presence of ground water, slope angle, removal of vegetation cover, lack of proper drainage system, artificial changing, climatological setting, geological characteristics and material characteristics are additional factors contributing to the failures.

Table 3 shows the results of a detailed analysis of rock slope failures. The main factor contributing to rock slope failures was the orientation and intensity of discontinuity planes (Figures $10 \& 11$ ). That is why rock slope failures occur most frequently along the highway on meta-sediment and sedimentary rocks, which were highly brecciated and fractured. Generally the failed material underwent only moderately to completely weathering (grade III to V). The rock properties characterization for 10 rock samples indicated that point load strength index ranges from $0.30 \mathrm{MPa}$ to $0.48 \mathrm{MPa}$ (moderately week). Kinematics slope analyses indicates that the variable potential of circular, planar, wedges and toppling failures modes as well as the combination of more than one mode of aforementioned failure. Rock slopes stability analysis indicates that the factor of safety value as unsafe ( 0.68 to 0.92 ). Other factors contributing to rock slope failure are the presence of groundwater, climatological setting, joints filling material high degree of rock fracturing due to shearing, steep of slope angle, high intensive of faulting and folding activities and locating at the fault zones area.

Table 2: Analysis results of soil slope failures

\begin{tabular}{|c|c|c|c|c|c|c|c|c|c|c|}
\hline \multirow{2}{*}{$\begin{array}{c}\begin{array}{c}\text { Type of } \\
\text { failure }\end{array} \\
\text { Slope No. }\end{array}$} & \multicolumn{2}{|c|}{$\begin{array}{l}\text { Shallow } \quad \text { slide } \\
\text { (T1 -a) }\end{array}$} & \multicolumn{2}{|c|}{$\begin{array}{l}\text { Deep slide (T1 - } \\
\text { b) }\end{array}$} & \multicolumn{2}{|l|}{$\begin{array}{l}\text { Multiple } \\
\text { (T2-b) }\end{array}$} & \multicolumn{2}{|c|}{$\begin{array}{l}\text { Complex failure } \\
\text { (Slide Flow) (T5 - } \\
\text { a) }\end{array}$} & \multicolumn{2}{|c|}{$\begin{array}{l}\text { Complex failure } \\
\text { (Slump flow) (T5 } \\
\text { - b) }\end{array}$} \\
\hline & SS2 & SS5 & SS1 & SS7 & SS3 & SS8 & SS4 & SS10 & SS9 & SS6 \\
\hline & $\begin{array}{l}\text { Trusm } \\
\text { adi } \\
\text { Format } \\
\text { ion }\end{array}$ & $\begin{array}{l}\text { Crocke } \\
\mathrm{r} \\
\text { Format } \\
\text { ion }\end{array}$ & $\begin{array}{l}\text { Crocker } \\
\text { Formati } \\
\text { on }\end{array}$ & $\begin{array}{l}\text { Crocke } \\
r \\
\text { Format } \\
\text { ion }\end{array}$ & $\begin{array}{l}\text { Crocker } \\
\text { Formatio } \\
\mathrm{n}\end{array}$ & $\begin{array}{l}\text { Crocker } \\
\text { Formati } \\
\text { on }\end{array}$ & $\begin{array}{l}\text { Crocker } \\
\text { Formatio } \\
\mathrm{n}\end{array}$ & $\begin{array}{l}\text { Crocke } \\
r \\
\text { Format } \\
\text { ion }\end{array}$ & $\begin{array}{l}\text { Crocker } \\
\text { Formati } \\
\text { on }\end{array}$ & $\begin{array}{l}\text { Crocke } \\
r \\
\text { Format } \\
\text { ion }\end{array}$ \\
\hline Lithology & $\begin{array}{l}\text { Sub- } \\
\text { Phyllit } \\
\text { e }\end{array}$ & $\begin{array}{l}\text { Sedime } \\
\mathrm{nt}\end{array}$ & $\begin{array}{l}\text { Interbe } \\
\text { d- } \\
\text { ded } \\
\text { Sandsto } \\
\text { ne \& } \\
\text { Shale }\end{array}$ & $\begin{array}{l}\text { Sedime } \\
\text { nt }\end{array}$ & $\begin{array}{l}\text { Sub- } \\
\text { Phyllite }\end{array}$ & $\begin{array}{l}\text { Interbe } \\
\text { d- } \\
\text { ded } \\
\text { Sandsto } \\
\text { ne \& } \\
\text { Shale }\end{array}$ & $\begin{array}{l}\text { Interbed } \\
- \\
\text { ded } \\
\text { Sandston } \\
\text { e \& Shale }\end{array}$ & $\begin{array}{l}\text { Interb } \\
\text { ed- } \\
\text { ded } \\
\text { Sandst } \\
\text { one \& } \\
\text { Shale }\end{array}$ & $\begin{array}{l}\text { Interbe } \\
\text { d- } \\
\text { ded } \\
\text { Sandsto } \\
\text { ne \& } \\
\text { Shale }\end{array}$ & $\begin{array}{l}\text { Sedime } \\
\text { nt }\end{array}$ \\
\hline $\begin{array}{l}\text { Weathering } \\
\text { grade }\end{array}$ & IV to VI & IV to VI & IV to VI & IV to VI & IV to VI & IV to VI & IV to VI & IV to VI & IV to VI & IV to VI \\
\hline Volume (1) & $\begin{array}{l}\text { Mediu } \\
\mathrm{m}\end{array}$ & $\begin{array}{l}\text { Mediu } \\
\mathrm{m}\end{array}$ & Large & Large & Small & Small & Medium & Small & Medium & Large \\
\hline Sand (\%) & $22-25$ & $65-68$ & $59-63$ & $68-70$ & $36-40$ & $51-54$ & $40-42$ & $46-49$ & $55-59$ & $48-51$ \\
\hline Silt (\%) & $54-57$ & $8-12$ & $8-10$ & $16-18$ & $23-26$ & $21-24$ & $18-25$ & $23-25$ & $16-19$ & $7-11$ \\
\hline Clay (\%) & $22-24$ & $22-24$ & $30-35$ & $15-16$ & $38-45$ & $37-39$ & $38-43$ & $25-29$ & $28-32$ & $38-42$ \\
\hline $\begin{array}{l}\text { Liquid limit } \\
(\%)\end{array}$ & $25-29$ & $27-30$ & $25-32$ & $28-32$ & $43-44$ & $29-32$ & $41-45$ & $33-37$ & $335-40$ & $29-32$ \\
\hline $\begin{array}{l}\text { Plastic limit } \\
(\%)\end{array}$ & $12-14$ & $12-14$ & $11-14$ & $17-18$ & $18-24$ & $16-20$ & $23-27$ & $23-27$ & $17-22$ & $13-17$ \\
\hline $\begin{array}{l}\text { Plasticity } \\
\text { index (\%) }\end{array}$ & $14-18$ & $13-16$ & $12-19$ & $15-17$ & $18-19$ & $18-21$ & $18-23$ & $14-17$ & $15-18$ & $18-21$ \\
\hline
\end{tabular}




\begin{tabular}{|c|c|c|c|c|c|c|c|c|c|c|}
\hline $\begin{array}{l}\text { Liquidity index } \\
\text { (\%) }\end{array}$ & $\begin{array}{l}-0.36 \\
\text { to } \\
0.31\end{array}$ & $\begin{array}{l}0.02 \text { to } \\
0.04\end{array}$ & $\begin{array}{l}-0.03 \text { to } \\
-0.03\end{array}$ & $\begin{array}{l}-1.56 \\
\text { to } \\
1.53\end{array}$ & $\begin{array}{l}-0.86 \text { to }- \\
0.80\end{array}$ & $\begin{array}{l}-0.67 \text { to } \\
0.18\end{array}$ & $\begin{array}{l}-0.81 \text { to }- \\
0.79\end{array}$ & $\begin{array}{l}0.02 \text { to } \\
0.50\end{array}$ & $\begin{array}{l}0.42 \text { to } \\
0.76\end{array}$ & $\begin{array}{l}0.18 \text { to } \\
0.20\end{array}$ \\
\hline Clay activity & $\begin{array}{l}0.99- \\
1.00\end{array}$ & $\begin{array}{l}0.34- \\
0.40\end{array}$ & $\begin{array}{ll}0.88 & - \\
0.94 & \end{array}$ & $\begin{array}{ll}0.66- \\
0.75\end{array}$ & $\begin{array}{ll}1.45 & - \\
1.47 & \\
\end{array}$ & $\begin{array}{ll}0.89 & - \\
0.97 & \\
\end{array}$ & $\begin{array}{ll}0.43 & - \\
0.50 & \\
\end{array}$ & $\begin{array}{l}0.97- \\
1.10\end{array}$ & $\begin{array}{l}0.59 \\
0.68\end{array}$ & $\begin{array}{ll}0.38 & - \\
0.47 & \\
\end{array}$ \\
\hline $\begin{array}{l}\text { Shrinkage } \\
\text { limit (\%) }\end{array}$ & $\begin{array}{ll}8.67- \\
8.88\end{array}$ & $\begin{array}{l}6.10- \\
6.35\end{array}$ & $\begin{array}{ll}8.55 & - \\
9.12 & \end{array}$ & $\begin{array}{ll}7.04- \\
7.65\end{array}$ & $\begin{array}{ll}8.45 & - \\
9.28 & \\
\end{array}$ & $\begin{array}{ll}9.56- \\
9.89\end{array}$ & $\begin{array}{ll}7.98 & - \\
8.68 & \\
\end{array}$ & $\begin{array}{l}9.65- \\
9.87\end{array}$ & $\begin{array}{l}8.43 \\
8.70\end{array}$ & $\begin{array}{l}8.22- \\
10.54 \\
\end{array}$ \\
\hline $\begin{array}{l}\text { Moisture } \\
\text { content (\%) }\end{array}$ & $5-12$ & $10-12$ & $15-18$ & $7-10$ & $8-11$ & $31-35$ & $9-13$ & $19-23$ & $30-32$ & $14-17$ \\
\hline $\begin{array}{l}\text { Specific } \\
\text { gravity }\end{array}$ & $\begin{array}{l}2.61- \\
2.64 \\
\end{array}$ & $\begin{array}{l}2.76- \\
2.78 \\
\end{array}$ & $\begin{array}{ll}2.63 & - \\
2.64 & \\
\end{array}$ & $\begin{array}{ll}2.73- \\
2.77\end{array}$ & $\begin{array}{ll}2.61 & - \\
2.69 & \\
\end{array}$ & $\begin{array}{ll}2.9 & - \\
2.68 & \\
\end{array}$ & $\begin{array}{ll}2.63 & - \\
2.68 & \\
\end{array}$ & $\begin{array}{l}2.51- \\
2.58\end{array}$ & $\begin{array}{ll}2.68 & - \\
2.73 & \end{array}$ & $\begin{array}{l}2.65 \\
2.68 \\
\end{array}$ \\
\hline $\begin{array}{l}\text { Permeability } \\
(\mathrm{cm} / \mathrm{s}) \\
\left(\mathrm{X} \mathrm{10} \mathbf{1 0}^{-3}\right) \\
\end{array}$ & 3.28 & 9.15 & 5.55 & 8.28 & 5.56 & 9.07 & 4.35 & 5.19 & 6.64 & 8.47 \\
\hline $\begin{array}{ll}\begin{array}{l}\text { Cohesion, } \\
\left(\mathrm{kN} / \mathrm{m}^{2}\right)\end{array} & \mathrm{C} \\
\end{array}$ & 5.11 & 6.78 & 11.67 & 6.27 & 15.34 & 17.77 & 12.45 & 19.62 & 24.44 & 8.53 \\
\hline $\begin{array}{l}\text { Friction angle } \\
\left({ }^{\circ}\right)\end{array}$ & 7.72 & 28.90 & 11.90 & 22.90 & 22.36 & 19.43 & 21.55 & 19.40 & 11.70 & 20.45 \\
\hline $\begin{array}{ll}\text { Factor } & \text { of } \\
\text { Safety } & \\
\end{array}$ & 0.68 & 0.95 & 0.88 & 0.76 & 0.65 & 0.89 & 0.56 & 0.94 & 0.90 & 0.92 \\
\hline $\begin{array}{l}\text { Main factors } \\
\text { causing } \\
\text { failures }\end{array}$ & SA, W, & $\mathrm{L}, \mathrm{il}$ & , OBV, L & $\mathrm{EC}$ and $\mathrm{A}$ & & & & & & \\
\hline
\end{tabular}

Note: (1) Volume: small $\left(10-50 \mathrm{~m}^{3}\right)$, Medium $\left(50-500 \mathrm{~m}^{3}\right)$ and Large $\left(>500 \mathrm{~m}^{3}\right)$ and (2) Discontinuity (D), Slope angle (SA), Weathering (W), Vegetation (V), Groundwater level (GWL), Material characteristics (M), Climatological setting (C), Geological characteristics (G), Over burden or vibration (OBV), Drainage system (DS), Embankment construction (EC) and Artificial changing (AC)

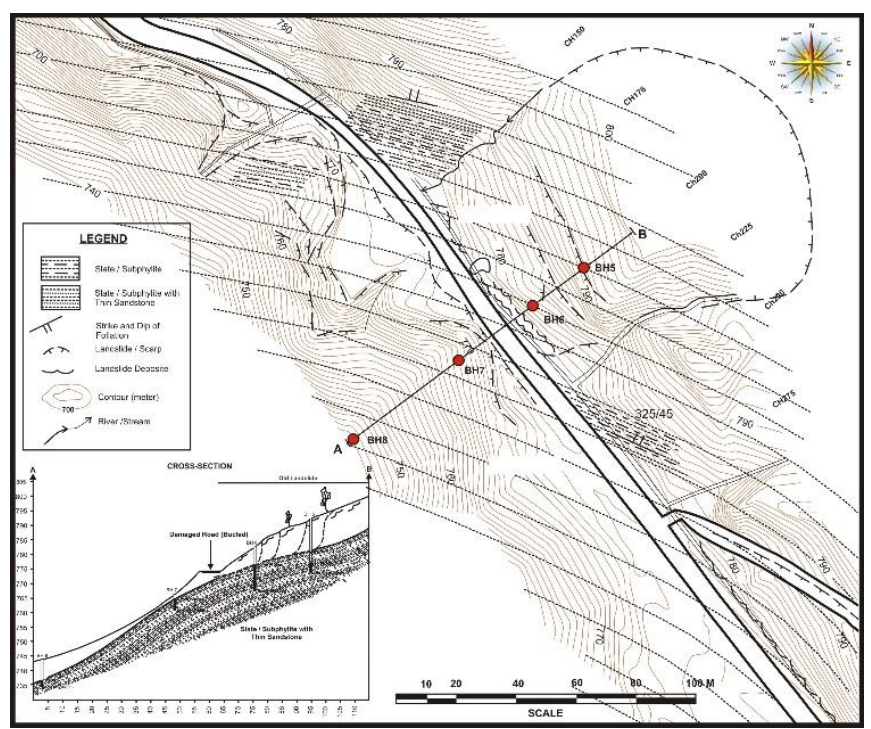

Figure 3: Sketch of slope failure showing the failure movement are starting from the hill side to the road sides through the development of water runoff (Location: SS 4) [22]

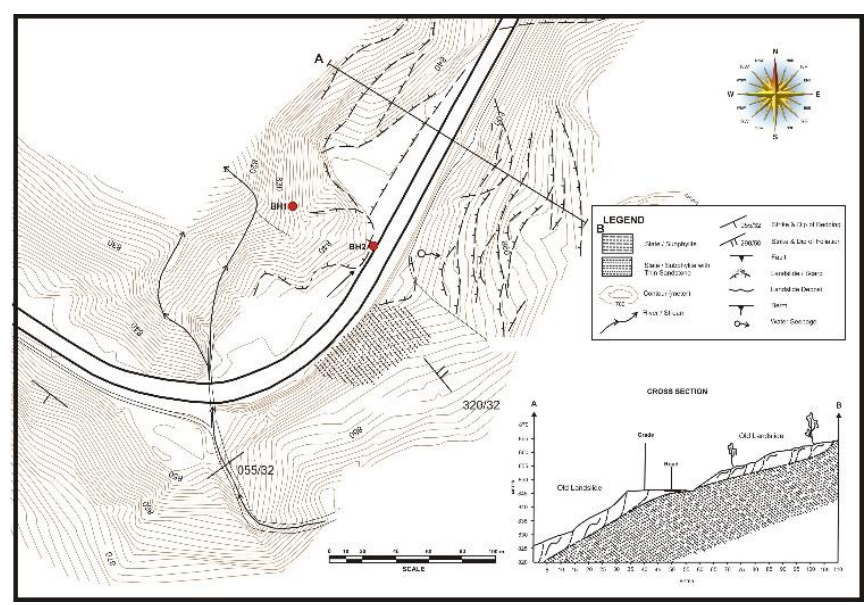

Figure 4: Sketch of slope failure showing the movement pattern is to collapse at the head, fall rapidly within narrow tracks, finally dispersing across the accumulation talus deposits (Location: SS 9) [23].

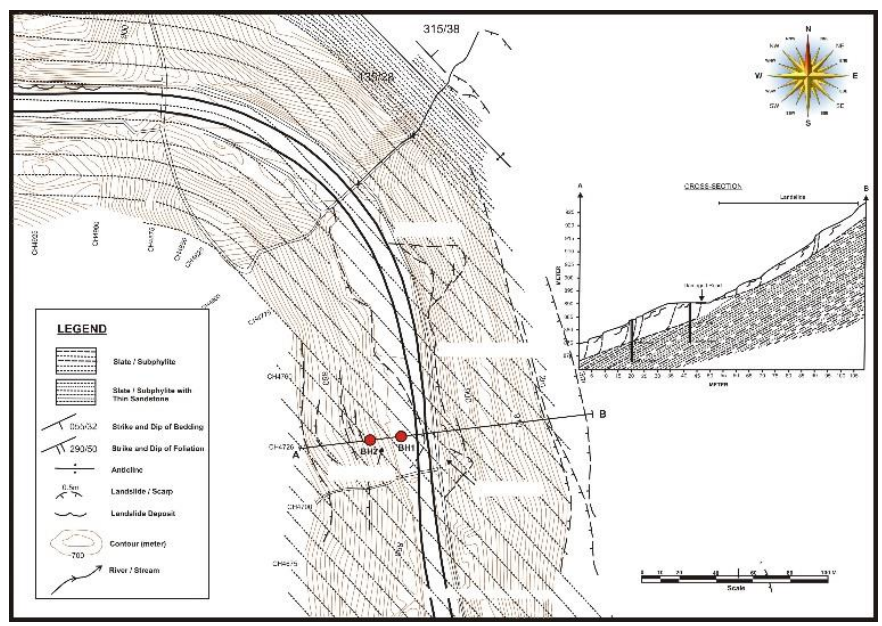

Figure 5: Sketch of slope failure showing the morphological features, which have their whole failure mass is the pear-shaped scar and the presence of an extensive flow features on the lower side of the scar (Location: RS 6)

\section{DISCUSSION}

The steep and hummocky topography terrain in the study area is naturally slope instability prone areas. Intense water runoff systems in this steep rugged terrain are characterised by short and rapid flowing streams. These fast moving bodies of water, causes surface erosion and gulling on the slopes. Surface erosion removes the necessary top soil to sustain vegetation cover. This further exposes the slope and weakens the strength of the slope materials. The steep slope also poses real problems for infrastructural developments, like road construction. Due to this reason, construction of roads across the mountain range would definitely involve slope cutting and building of fill slopes.

The geology of the Trusmadi and Crocker Formations does not benefit slope stability. The argillaceous of phyllite and slate lithology of the Trusmadi Formation and the interbedded sandstone-shale and shale unit lithology of the Crocker Formation weather rapidly when exposed to the elements. This is especially through along many man-made slope cuts. Weathering changes the phyllite, slate, sandstone and shale into fine clayey materials. Determined indirectly from their clay activity values some of these clay minerals are suspected to be in-active and normal clay. 
These two types of clay minerals when interacting with water would expand and lubricate rock joints and other discontinuities.

The highly fractured nature of the lithology also contributes to slope instability. Fractured rock masses have much lower shear strength compared to the original fresh rock. The orientation of the discontinuities and its relation to the geometry and strike of the slope, have a direct influence on the occurrence of rock slope failures. Due to the influence of the regional tectonic forces the rock joints in the study area are predominantly orientated at a Northeast - Southwest and Northwest Southeast direction. It has been determined that slopes that strike northward, westward, and South - Southeast show a higher probability to fails. Therefore as a matter of precaution, cutting the slopes at these strike directions, if possible should be avoided [24].

The climate of the study area is very much the same as the other parts of Sabah, Malaysia. The condition of a warm and moist tropical climate induces rapid weathering of the lithology forming thick weathering profiles. High annual rainfall is accumulated during periods of rainfall and drizzling which occur daily in this high mountainous region [25-27]. The high amount of rainfall helps to sustain the moist and wet nature of the slope throughout most of the day. During the storm's period of high rainfall intensity, the rate of water infiltration to the soil would not be sufficient, the excess water would accumulate to form surface run off. During intense storms, the amount of run off and deep percolation greatly exceeds the evapotranspiration. Excessive surface run off causes rapid surface erosion, which blocks the limited existing man made drainage. As the result of blocked and insufficient drainage the excess water overflows the drains and on to the road surface. The excess water would also accumulate on certain parts of the road and fill slope.

At several locations where the huge drainage pipes are buried underneath the road, subsidence is seen to occur. Where the outlet of the drainage pipe (just below road level) directs the water down slope, erosion and undercutting of the fill slope is seen to occur [28]. This shows a weakness in the drainage design. The drainage pipes should be extended to the nearest natural drainage. Another important contribution to slope failure is the anthropological factor. Man is solely responsible in the faulty design and construction of unstable slope cuts. In the study area man's road construction is responsible for much of the failure of fill slopes. Due to the rugged and hummocky topography sections of the road were built across natural drainage valleys. Without proper drainage, the fill slope blocks the path of water flow [29-30]. The retention of water at these slopes, caused subsidence and tension cracks to appear on the road surface [22]. If left unchecked, total failure would occur at these sections of road. Lack of maintenance is another real problem, which slopes are left without proper care until landslides have occurred. Other contributing anthropological factor includes the heavy traffic flow, illegal deforestation of slopes and irresponsible slope land development.

Factor of safety (FOS) provides away for an engineering assessment of slope stability. Slope stability analyses were conducted for various conditions such as the existence of tension cracks and variation of shear strength parameters in order to study the dominant factors causing the slope failure. Rock and soil slopes stability analysis indicates that the FOS value as unsafe ( 0.56 to 0.95 ). The location of slip circles also tally well with the slope failures as observed in the field. This confirms that the mobilised strength during the slope failure is very close to the subsoil peak strength parameter interpreted from the laboratory strength test results. Any rise in groundwater profile would certainly further reduce the FOS. In dealing with risk of slope failure, level of awareness and mitigation measures must be increased when there is obvious climatic change especially on rainy season.

\section{CONCLUSIONS}

In light of available information, the following conclusions may be drawn from the present study:

a. Physical and mechanical properties of 80 soil samples indicated that the failure materials mainly consist of poorly graded to well graded materials of sandy clay and clayey silt soils, which characterized by low to intermediate plasticity content (12\% to $21 \%$ ), containing of inactive to normal clay ( 0.34 to 1.47$)$, very high to medium degree of swelling $(6.10$ to 10.54 ), variable low to high water content ( $5 \%$ to $35 \%$ ), specific gravity ranges from 2.51 to 2.77 , low permeability $\left(9.15 \times 10^{-3}\right.$ to $3.28 \times 10^{-3}$ $\mathrm{cm} / \mathrm{s})$, friction angle $(\phi)$ ranges from $7.72^{\circ}$ to $28.90^{\circ}$ and cohesion (C) ranges from $5.11 \mathrm{KPa}$ to $24.44 \mathrm{KPa}$. Soil slopes stability analysis indicates that the factor of safety value as unsafe (0.68 to 0.95 ).

b. The rock properties characterization for 10 rock samples indicated that point load strength index ranges from $0.30 \mathrm{MPa}$ to $0.48 \mathrm{MPa}$ (moderately week). Kinematics slope analyses indicates that the variable potential of circular, planar, wedges and toppling failures modes as well as the combination of more than one mode of aforementioned failure.

c. Rock and soil slopes stability analysis indicates that the factor of safety value as unsafe ( 0.56 to 0.95 ).

d. Six (6) related main factor parameters to the landslide occurrence in the study area were attributed; 1) local and regional geology, 2) hydrological and geohydrological, 3) mineralogical and micro structures, 4) local discontinuities structures, 5) physical and engineering properties of soil and rock, and 6) geomorphological processes which can help in evaluating landslide problems.

\section{REFERENCES}

[1] Faisal, M.M., Tahir, S.H., Edward Voo, L.Z. 1998. Evaluation of environmental hazards related to the geologic setting of the Kota Kinabalu-Tambunan Road. Malaysian Science and Technology Congress. Symposium D: Biodiversity \& Environmental Sciences, Kota Kinabalu, Sabah, Malaysia.

[2] Komoo, I., Salleh, H., 2003. Living with Danger: Kundasang's Active Landslide. In Salleh, H., Othman, M., Komoo, I., \& Aziz, S., (Eds). Culture and Science of Mountains. LESTARI, UKM, Publication, Bangi, 213-223.

[3] Roslee, R., Tahir, S. 2004. Slope Failure Assessments along Bundu Tuhan to Kundasang Area, Sabah, Malaysia. Proc. of the IEM and GSM Forum 2004. Universiti Malaya, Kuala Lumpur, Malaysia. 15p.

[4] Roslee, R., Tahir, S. 2005. Combined Hydrology - Slope Stability Assessment in Kundasang Area, Sabah, Malaysia. Proc. of the International Conference on Monitoring, Prediction and Mitigation of Water-Related Disasters (MPMD 2005). ISBN4-902712-01-6. Clock Tower Centennial Hall, Kyoto University, Kyoto, Japan, 519-525.

[5] Laming, A., Roslee, R. 2005. Study of Mass Movement along Bundu Tuhan to Kundasang Highway, Sabah, Malaysia. Fundamental Research Grant Scheme (UMS Coded: B-0201-01-ER/U0038).

[6] Roslee, R., Tahir, S., Kadir, S.A., Omang, S. 2006. Engineering Geology of the Kota Kinabalu Area, Sabah, Malaysia. Bulletin of the Geological Society of Malaysia, 52, 17-25.

[7] Roslee, R., Tahir, S., Kadir, S.A., Omang, S. 2007. Engineering Geological Investigation on Slope Stability in the Sandakan Town Area, Sabah, Malaysia. Proc. of the 2nd Malaysia - Japan Symposium on Geohazards and Geoenvironmental Engineering. City Bayview Hotel, Langkawi, Malaysia, 17-27.

[8] Roslee, R., Zawawi, N.S.A., Tahir, S., Kadir, S.A., Omang, S. 2008. Engineering Geological Assessment of Slope Failure in the Ranau to Tambunan Area, Sabah, Malaysia. Proc. of the International Conference on Geotechnical \& Highway Engineering: GEOTROPIKA 2008. ISBN 978-98342623-4-4. Seri Pacific Hotel, Kuala Lumpur, Malaysia, 77-84.

[9] Tating, F.F. 2006. Geological factors contributing to the landslide hazard area at the Tamparuli - Ranau Highway, Sabah, Malaysia. Proc. of International Symposium on Geotechnical Hazards: Prevention, Mitigation and Engineering Response, Utomo, Tohari, Murdohardono, Sadisun, Sudarsono \& Ito (Eds), ISBN: 979-8636-13-9. Yogyakarta, Indonesia. 10p.

[10] Tongkul, F. 2007. Geological inputs in road design and construction in mountainous areas of West Sabah, Malaysia. Proc. of the $2^{\text {nd }}$ Malaysia- 
Japan Symposium on Geohazards and Geoenvironmental Engineering. City Bayview Hotel, Langkawi, 39-43.

[11] Roslee, R., Tongkul, F. 2018. Engineering Geological Assessment (EGA) on Slopes Along the Penampang to Tambunan Road, Sabah, Malaysia. Malaysian Journal of Geosciences, 2 (1), 06-14.

[12] Mineral and Geosciences Department of Malaysia (former Geological Survey Department of Malaysia). 1994. Landslide, Rock falls and Road Subsidence's along the Tamparuli - Ranau Highway. Sec. Edit. Bahagian Perkhidmatan Geologi. Report SB/EG/94/1.

[13] Komoo, I., Salleh, H., Djin, T.H., Aziz, S., Tongkul, F., Jamaluddin, T.A., Sian, L.C., Mohd Said, M.Y., Man, Z. 2004. Landslide Assessment and Control: An Integrated Approach. Presented at Kundasang Landslides Complex: Hazard Assessment and Control Seminar, 25th May 2004, Sabah.

[14] Komoo, K. 1985. Pengelasan Kegagalan Cerun di Malaysia. Jurnal Ilmu Alam, 14-15.

[15] British Standard BS 5930. 1981. Site Investigation. London: British Standard Institution.

[16] British Standard BS 1377. 1990. Methods of Test for Soils for Civil Engineering Purposes. London: British Standard Institution.

[17] ISRM. 1979a. Suggested methods for determining water content, porosity, density, absorption and related properties, and swelling and slake-durability index properties. ISRM Commission on Standardization of Laboratory and Field Tests. International Journal of Rock Mechanics and Mining Sciences, 16, 141-156.

[18] ISRM. 1979b. Suggested methods for determining the uniaxial compressive strength and deformability of rock materials. ISRM Commission on Standardization of Laboratory and Field Tests. International Journal of Rock Mechanics and Mining Sciences, 16, 135-140.

[19] ISRM. 1985. Suggested methods for determining point load strength. ISRM Commission on Standardization of Laboratory and Field Tests. International Journal of Rock Mechanics and Mining Sciences, 22 (2), 5160. [24] Edward Voo, L. Z. 1999. Slope Stability Analysis along Kota Kinabalu - Tambunan Road, Sabah. M. Phil. Thesis, University Malaysia Sabah (Unpublished).

[20] Geoslope International Ltd. 2002. Slope/W User's guide for slope stability analysis. Version 5., Calgary, Alta, Canada.

[21] Watts, C. F. 2003. ROCKPACK III for Windows. ROCK Slope Stability Analysis Package. User's Manual. Radford Computerized University, Radford, Virginia

[22] Tongkul, F., Benedick, H., Khiong, C.F. 2006. Geology of selected site along Ranau to Tambunan road (KM 13.5 - KM 23.5), Sabah. Consultancy Project Report. Client: Perunding Menara HAC Sdn Bhd.

[23] Tongkul, F., Benedick, H., Khiong, C.F. 2004. Geology of selected slopes along Keningau to Kimanis road, Sabah. Consultancy Project Report. Client: PC Konsultant JV Utama Jurutera Perunding.

[24] Tongkul, F. 1989. Weak zones in the Kota Kinabalu area, Sabah, East Malaysia. Sabah Society Journal, Volume IX, No. 1, 11.

[25] Jacobson. G. 1970. Gunong Kinabalu area, Sabah, Malaysia. Sabah: Geological Survey Malaysia Report 8.

[26] Sánchez, M.A., Foyo, A., Tomillo, C., Iriarte, E. 2007. Geological risk assessment of the area surrounding Altamira Cave: A proposed Natural Risk Index and Safety Factor for protection of prehistoric caves. Engineering Geology, 94, 180-200.

[27] Roslee, R. 2004. Study of Mass Movement along Bundu Tuhan to Kundasang Highway, Sabah, Malaysia. MSc Thesis. Unpublished. Universiti Malaysia Sabah.

[28] Edbrooke, S.W., Mazengarb, C., Stephenson, W. 2003. Geology and geological hazards of the Auckland urban area, New Zealand. Quaternary International, 103, 3-21.

[29] Tjia, H.D. 1974. Sense of tectonic transport in intensely deformed
Trusmadi and Crocker sediments, Ranau - Tenompok area, Sabah. Sains Malaysiana, 3 (2), 129 - 166.

[30] Tongkul, F. 1987. Sedimentary and structure of the Crocker Formation in the Kota Kinabalu area, Sabah, East Malaysia. Ph. D. Thesis, University London (Unpublished).

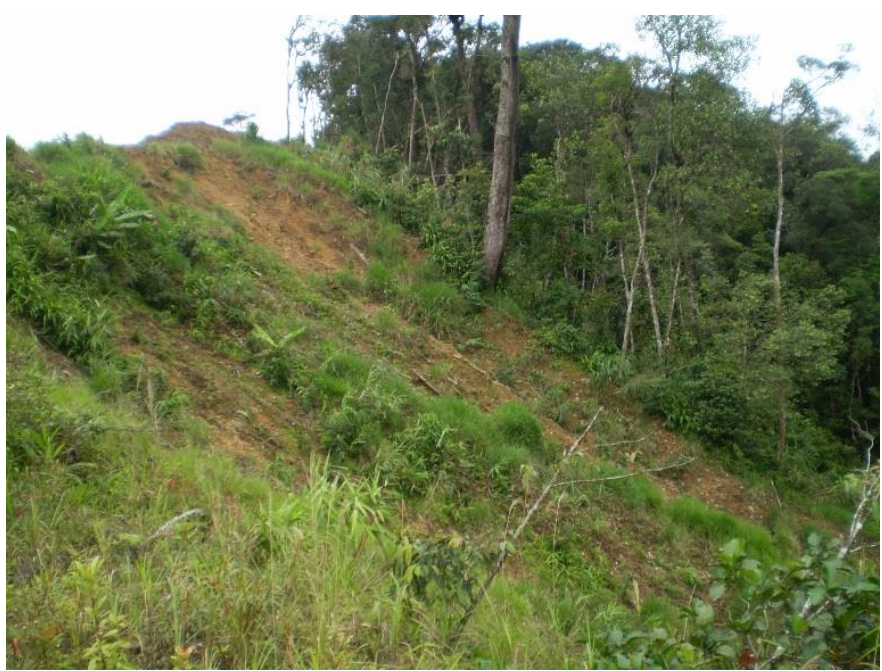

Figure 6: Shallow slide (T1 - a) at SS 1 shows the failure movement are starting to move into several discrete blocks through the development of transverse cracks

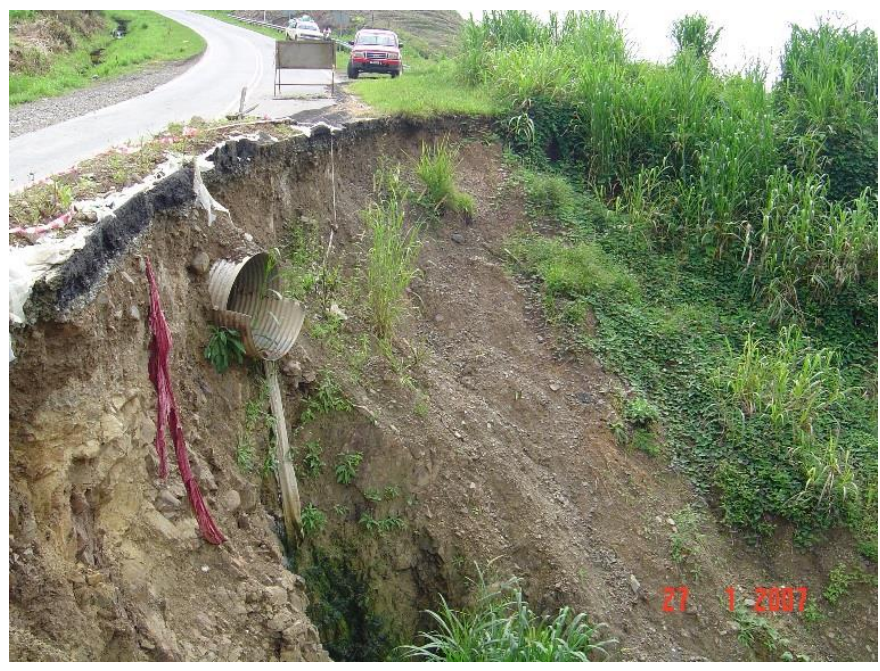

Figure 7: Embankment failure in the form of a deep slide (T1 - b) at SS 6

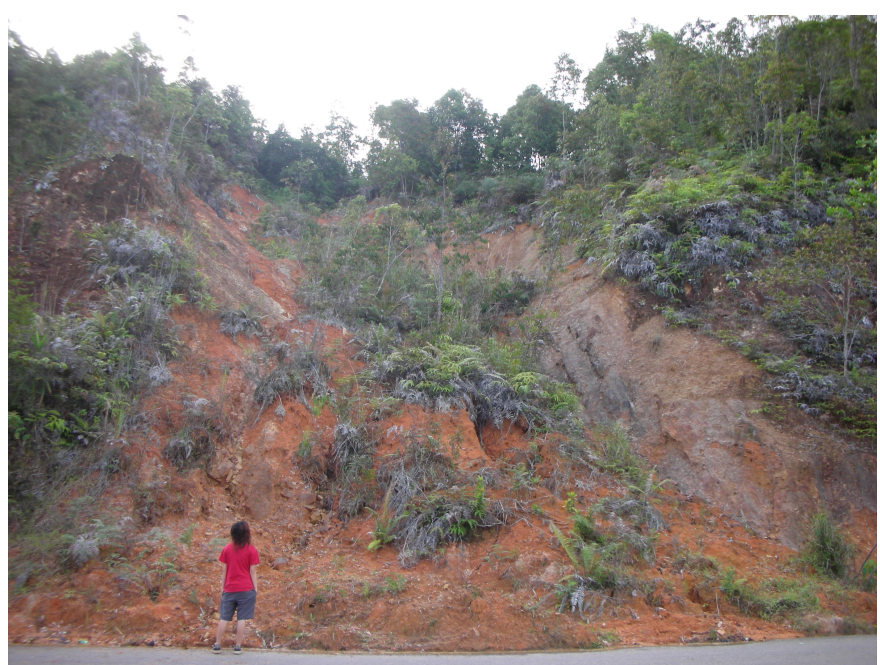

Figure 8: Multiple slump (T2-b) showing the settling slope material suffers from fracturing, stumping or flowing considerable lateral movement along the slip plane of the down slope (Location: SS 8) 


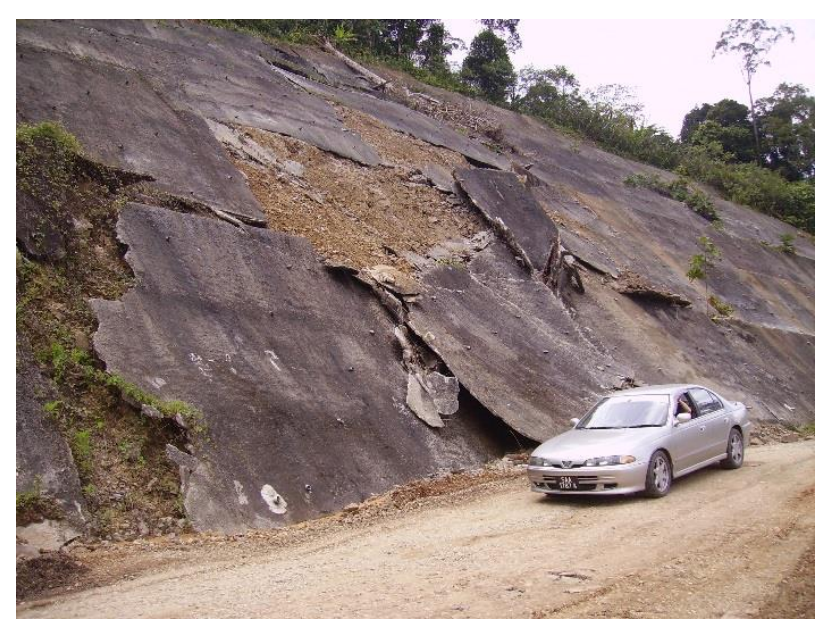

Figure 9: Complex failure (slump flow) (T5 - b) at SS 10) shows the landslide scarp above the road showing the vertical displacement

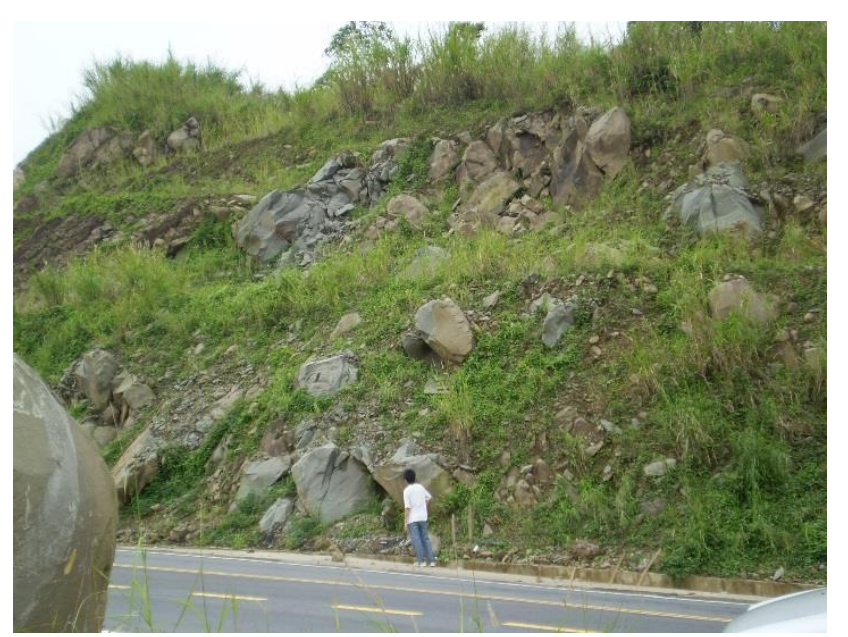

Figure 10: Circular failure (crushed) (B1 - b) at RS 10 shows the surface weakness (revealing) within the structure, which composed of coherent crushed rocks on the gently sloping discontinuities

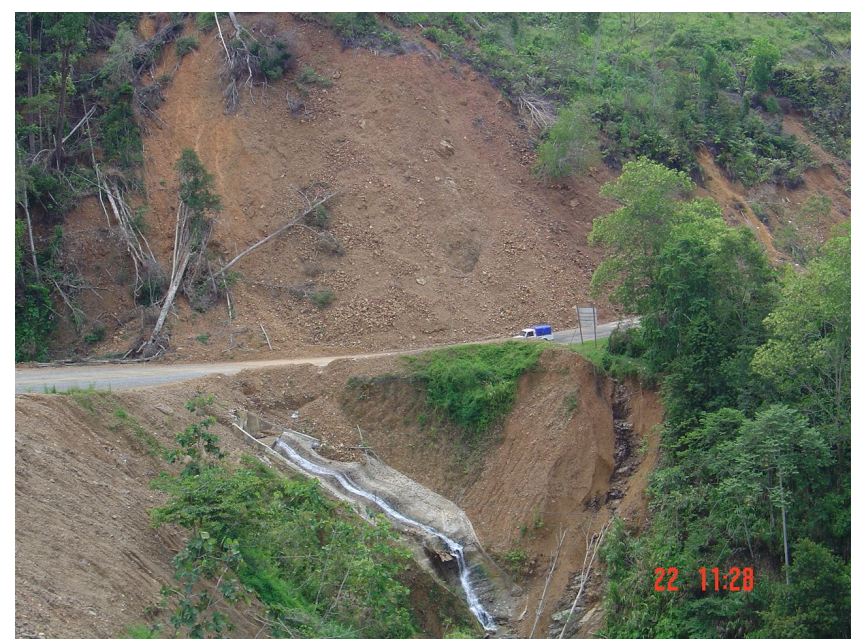

Figure 11: Wedge failure (blocks and fragments) (B3 - a) at RS 3 indicates the form of discontinuities provides intersecting sheets to form yield stepped surfaces or boundary vertical joints

Table 3: Analysis results of rock slope failures

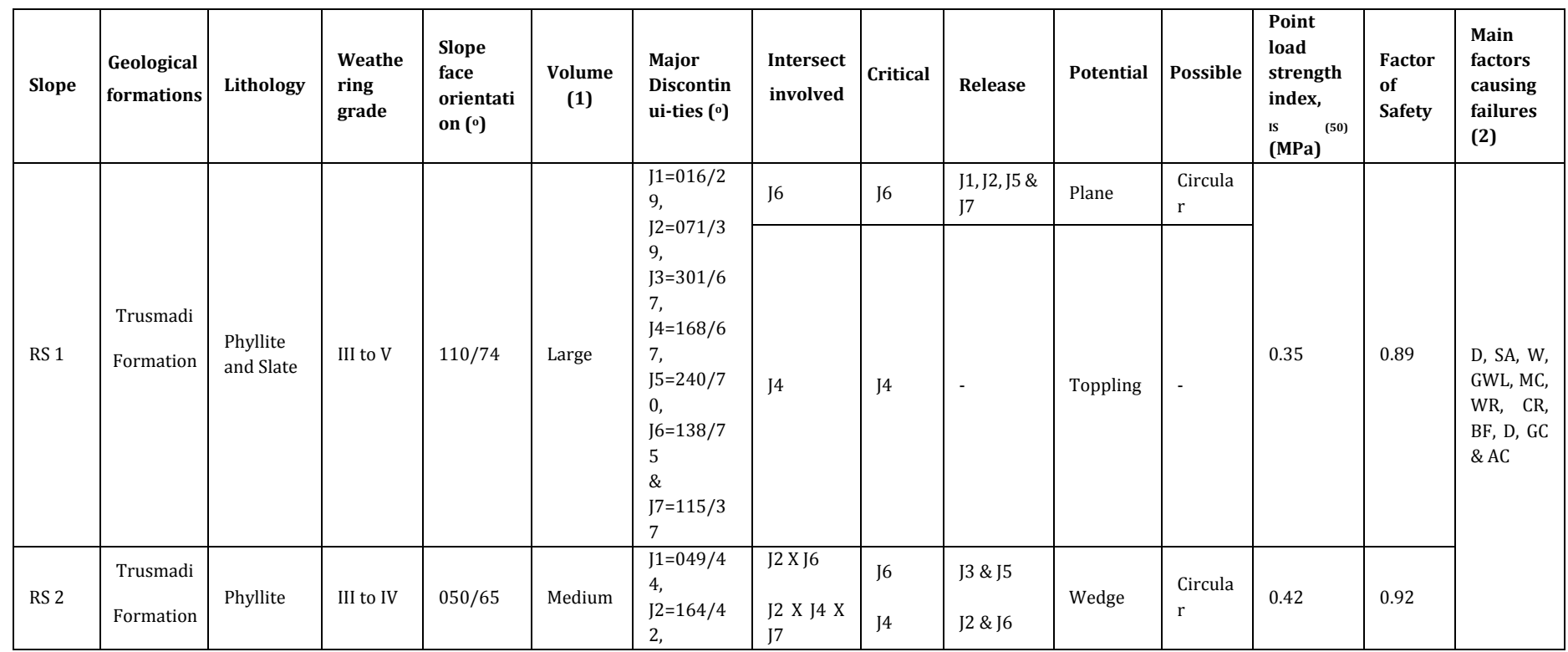




\begin{tabular}{|c|c|c|c|c|c|c|c|c|c|c|c|c|c|}
\hline & & & & & & $\begin{array}{l}J 3=250 / 3 \\
4, \\
J 4=305 / 2 \\
7, \\
J 5=343 / 5 \\
1, \\
J 6=111 / 3 \\
0 \\
\& \\
J 7=210 / 3 \\
6\end{array}$ & $\mathrm{~J} 5$ & J5 & $\begin{array}{l}\mathrm{J} 1, \mathrm{~J} 3, \mathrm{~J} 4, \\
\mathrm{~J} 6 \text { \& J7 }\end{array}$ & & Toppling & & \\
\hline \multirow[b]{2}{*}{ RS 3} & \multirow[b]{2}{*}{$\begin{array}{l}\text { Crocker } \\
\text { Formation }\end{array}$} & \multirow[b]{2}{*}{$\begin{array}{l}\text { Interbedd } \\
\text { ed } \\
\text { Sandston } \\
\text { e \& Shale }\end{array}$} & \multirow[b]{2}{*}{ III to $\mathrm{V}$} & \multirow[b]{2}{*}{$125 / 78$} & \multirow[b]{2}{*}{ Medium } & \multirow{2}{*}{$\begin{array}{l}\mathrm{J} 1=171 / 4 \\
5, \\
\mathrm{~J} 2=066 / 6 \\
8, \\
\mathrm{~J} 3=301 / 6 \\
6, \\
\mathrm{~J} 4=018 / 7 \\
6, \\
\mathrm{~J} 5=241 / 7 \\
5, \\
\mathrm{~J} 6=339 / 7 \\
5 \\
\& \\
\mathrm{~J} 7=307 / 3 \\
0\end{array}$} & $\begin{array}{l}\mathrm{J} 3 \times \mathrm{J} 7 \\
\mathrm{~J} 1 \times \mathrm{J} 3 \\
\mathrm{~J} 1 \times \mathrm{J} 2 \\
\mathrm{~J} 2 \times \mathrm{J} 3\end{array}$ & $\begin{array}{l}\mathrm{J} 3 \\
\mathrm{~J} 1 \\
\mathrm{~J} 2 \\
\mathrm{~J} 2\end{array}$ & $\begin{array}{l}\mathrm{J} 4 \text { \& J5 } \\
\mathrm{J} 1, \mathrm{~J} 3 \text { \& } 5 \\
\mathrm{~J} 1, \mathrm{~J} 4 \mathrm{~J} 7 \\
\mathrm{~J} 1, \mathrm{~J} 3 \text { \& J7 }\end{array}$ & Wedge & Circular & & \\
\hline & & & & & & & $\mathrm{J} 6$ & J6 & $\begin{array}{l}J 1, J 2, J 3 \& \\
J 7\end{array}$ & - & Toppling & 0.48 & 0.89 \\
\hline \multirow[b]{2}{*}{ RS 4} & \multirow[b]{2}{*}{$\begin{array}{l}\text { Crocker } \\
\text { Formation }\end{array}$} & \multirow[b]{2}{*}{$\begin{array}{l}\text { Interbedd } \\
\text { ed } \\
\text { Sandston } \\
\text { e \& Shale }\end{array}$} & \multirow[b]{2}{*}{ III to $\mathrm{V}$} & \multirow[b]{2}{*}{$025 / 78$} & \multirow[b]{2}{*}{ Large } & \multirow[b]{2}{*}{$\begin{array}{l}\mathrm{J} 1=063 / 5 \\
3, \\
\mathrm{~J} 2=174 / 4 \\
6, \\
\mathrm{~J} 3=041 / 7 \\
4, \\
\mathrm{~J} 4=214 / 6 \\
1, \\
\mathrm{~J} 5=306 / 2 \\
9, \\
\mathrm{~J} 6=266 / 5 \\
4 \\
\& \\
\mathrm{~J} 7=163 / 6 \\
8\end{array}$} & $\begin{array}{l}\mathrm{J} 2 \times \mathrm{J} 3 \\
\mathrm{~J} 2 \times \mathrm{J} 6 \\
\end{array}$ & $\begin{array}{l}33 \\
\mathrm{~J} 2 \\
\end{array}$ & $\begin{array}{l}\mathrm{J} 2 \& \mathrm{~J} 6 \\
\mathrm{~J} 4 \text { \& } 6 \\
\end{array}$ & Wedge & Circular & & \\
\hline & & & & & & & $\mathrm{J4}$ & J4 & $\begin{array}{l}\mathrm{J} 1, \mathrm{~J} 2 \text { \& J5 } \\
\mathrm{J} 3, \mathrm{~J} 4 \text { \& J6 }\end{array}$ & Plane & - & 0.47 & 0.68 \\
\hline \multirow[b]{2}{*}{ RS 5} & \multirow[b]{2}{*}{$\begin{array}{l}\text { Crocker } \\
\text { Formation }\end{array}$} & \multirow[b]{2}{*}{$\begin{array}{l}\text { Interbedd } \\
\text { ed } \\
\text { Sandston } \\
\text { e \& Shale }\end{array}$} & \multirow[b]{2}{*}{ III to V } & \multirow[b]{2}{*}{$122 / 68$} & \multirow[b]{2}{*}{ Medium } & \multirow{2}{*}{$\begin{array}{l}\mathrm{J} 1=024 / 3 \\
2 \\
\mathrm{~J} 2=083 / 2 \\
8 \\
\mathrm{~J} 3=282 / 5 \\
6 \\
\mathrm{~J} 4=154 / 5 \\
7 \\
\mathrm{~J} 5=232 / 6 \\
6\end{array}$} & $\mathrm{~J} 5 \mathrm{x} \mathrm{J3}$ & J5 & $\mathrm{J} 1, \mathrm{~J} 2 \& \mathrm{~J} 5$ & Wedge & Circular & & \\
\hline & & & & & & & J4 & $\mathrm{J} 4$ & - & Toppling & - & 0.30 & 0.91 \\
\hline \multirow[b]{2}{*}{ RS 6} & \multirow[b]{2}{*}{$\begin{array}{l}\text { Crocker } \\
\text { Formation }\end{array}$} & \multirow[b]{2}{*}{$\begin{array}{l}\text { Interbedd } \\
\text { ed } \\
\text { Sandston } \\
\text { e \& Shale }\end{array}$} & \multirow[b]{2}{*}{ III to $\mathrm{V}$} & \multirow[b]{2}{*}{$216 / 72$} & \multirow[b]{2}{*}{ Medium } & \multirow[b]{2}{*}{$\begin{array}{l}J 1=046 / 4 \\
9 \\
J 2=168 / 4 \\
3 \\
J 3=082 / 5 \\
4 \\
J 4=198 / 5 \\
9 \\
J 5=320 / 2 \\
3 \\
J 6= \\
132 / 70\end{array}$} & $\begin{array}{l}\mathrm{J} 2 \times \mathrm{J} 5 \\
\mathrm{~J} 1 \mathrm{XJ} 4\end{array}$ & J2 & $\begin{array}{l}\mathrm{J1}, \mathrm{J} 2, \mathrm{~J} 4 \& \\
\mathrm{~J}\end{array}$ & Circular & Circular & 0.45 & 0.79 \\
\hline & & & & & & & $\mathrm{J} 2 \mathrm{XJ}^{4}$ & J2 & $\mathrm{J} 3$ \& J4 & Wedge & - & & \\
\hline \multirow[b]{2}{*}{ RS 7} & \multirow{2}{*}{$\begin{array}{l}\text { Crocker } \\
\text { Formation }\end{array}$} & \multirow{2}{*}{$\begin{array}{l}\text { Interbedd } \\
\text { ed } \\
\text { Sandston } \\
\text { e \& Shale }\end{array}$} & \multirow[b]{2}{*}{ III to IV } & \multirow[b]{2}{*}{$034 / 58$} & \multirow[b]{2}{*}{ Small } & \multirow{2}{*}{$\begin{array}{l}\mathrm{J} 1=038 / 3 \\
1 \\
\mathrm{~J} 2=157 / 4 \\
7 \\
\mathrm{~J} 3=248 / 3 \\
2 \\
\mathrm{~J} 4=296 / 2 \\
5 \\
\mathrm{~J} 5=104 / 2 \\
7\end{array}$} & $\begin{array}{l}\mathrm{J} 2 \mathrm{X} \mathrm{J3} \mathrm{X} \\
\mathrm{J} 5 \\
\mathrm{~J} 2 \mathrm{X} \mathrm{J4} \times \\
\mathrm{J} 7\end{array}$ & $\mathrm{~J} 4$ & $\begin{array}{l}\mathrm{J} 3 \text { \& J5 } \\
\mathrm{J} 2 \& \mathrm{~J} 5\end{array}$ & Circular & Wedge & 0.38 & 0.79 \\
\hline & & & & & & & J5 & $\mathrm{J} 5$ & $\begin{array}{l}\mathrm{J} 1, \mathrm{~J} 3, \mathrm{~J} 4 \\
\mathrm{~J} 6 \text { \& J7 }\end{array}$ & - & Toppling & & \\
\hline RS 8 & $\begin{array}{l}\text { Crocker } \\
\text { Formation }\end{array}$ & Sediment & III to IV & $050 / 65$ & Medium & $\begin{array}{l}J 1=016 / 2 \\
9, \\
J 2=071 / 3 \\
9,\end{array}$ & $\begin{array}{l}2 \mathrm{XJ6} \\
\mathrm{J} 2 \mathrm{X} \mathrm{J} 4 \mathrm{X} \\
\mathrm{J} 7\end{array}$ & $\mathrm{~J} 6$ & $\begin{array}{l}\mathrm{J} 3 \text { \& J5 } \\
\mathrm{J} 2 \text { \& } 6\end{array}$ & Wedge & Circular & 0.42 & 0.92 \\
\hline
\end{tabular}




\begin{tabular}{|c|c|c|c|c|c|c|c|c|c|c|c|c|c|}
\hline & & & & & & $\begin{array}{l}J 3=301 / 6 \\
7, \\
J 4=168 / 6 \\
7, \\
J 5=240 / 7 \\
0, \\
J 6=138 / 7 \\
5 \\
\& \\
J 7=115 / 3 \\
7\end{array}$ & J5 & $\mathrm{J} 5$ & $\begin{array}{l}J 1, J 3, J 4, \\
J 6 \& J 7\end{array}$ & - & Toppling & & \\
\hline RS 9 & $\begin{array}{l}\text { Crocker } \\
\text { Formation }\end{array}$ & Sediment & III to IV & $308 / 75$ & Medium & $\begin{array}{l}J 1=154 / 4 \\
5, \\
J 2=062 / 4 \\
7 \\
\& \\
J 3=303 / 3 \\
5\end{array}$ & J3 & J3 & $\mathrm{J} 1$ \& $\mathrm{J} 2$ & Plane & - & 0.41 & 0.65 \\
\hline RS 10 & $\begin{array}{l}\text { Crocker } \\
\text { Formation }\end{array}$ & Sediment & III to IV & $275 / 70$ & Large & $\begin{array}{l}J 1=096 / 1 \\
7, \\
J 2=161 / 1 \\
7 \\
\& \\
J 3=270 / 6 \\
3\end{array}$ & J3 & J3 & $\mathrm{J} 1$ \& $\mathrm{J}$ & Plane & - & 0.47 & 0.77 \\
\hline
\end{tabular}

- $\quad$ Note

(1) Volume: small $\left(10-50 \mathrm{~m}^{3}\right)$, Medium $\left(50-500 \mathrm{~m}^{3}\right)$ and Large $\left(>500 \mathrm{~m}^{3}\right)$

(2) Discontinuity (D), Slope angle (SA), Weathering (W), Groundwater level (GWL), Material characteristics (MC), Weak rock (WR), Crushed rock (CR), Blocks and fragments (BF), Debris (D), Geological characteristics (GC) and artificial changing (AC)

(3) Rock bolt (RB), Rock dowel (RD), Shotcrete (S) \& Rock horizontal drainage (RHD) 